\title{
Primary hepatic tubercular abscesses in an immunocompetent patient
}

\author{
Karan Manoj Anandpara, Yashant Aswani, Priya Hira
}

Seth G S Medical College and KEM Hospital, Mumbai, Maharashtra, India

\section{Correspondence to} Dr Yashant Aswani, aswaniyashant@gmail.com

Accepted 6 November 2014
CrossMark

To cite: Anandpara KM, Aswani Y, Hira P. BMJ Case Rep Published online: [please include Day Month Year] doi:10.1136/bcr-2014207855

\section{DESCRIPTION}

A 40-year-old man presented with a two-month history of right hypochondriac pain, fever, nausea and vomiting. He was diagnosed with pyogenic liver abscesses and received cephalosporin and aminoglycoside as treatment. Failure to improve, however, led to his referral to our service. He had lost 8 pounds over 2 months. On palpation, there was tender hepatomegaly. The remainder of the examination was unremarkable. Investigations revealed an elevated leucocyte count (14 400/ $\mathrm{mm}^{3}$ ) with a predominance of neutrophils (78\%) and deranged liver function tests. Ultrasound revealed partially liquefied liver abscesses. Findings on abdominal CT scan were multiple ill-defined, centrally hypodense, peripherally enhancing lesions scattered throughout the liver (figure 1). One of the abscesses was aspirated and cheesy material was obtained. The aspirate was positive for acid-fast bacilli (AFB; figure 2). Surprisingly, there were no signs of tuberculosis in the chest or abdomen. The patient was negative

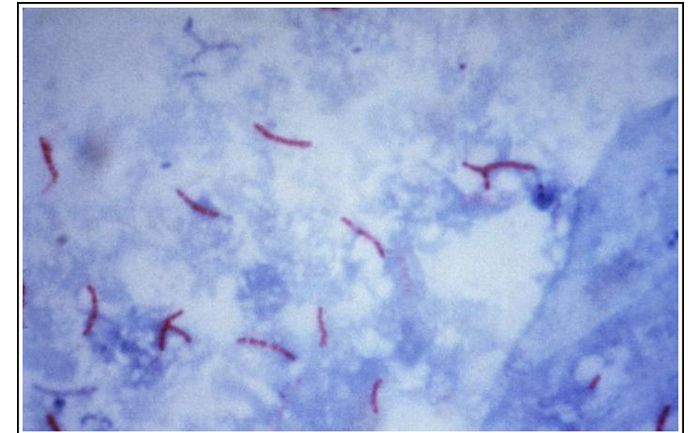

Figure 2 Ziehl-Neelsen staining of the aspirate was positive for acid-fast bacilli.

for HIV and other immunodeficient conditions. He was started on antitubercular drugs and has responded well to treatment.

Morphologically, hepatic tuberculosis can have five forms (Levine) ${ }^{1}$ : miliary tuberculosis, primary pulmonary tuberculosis with liver involvement,

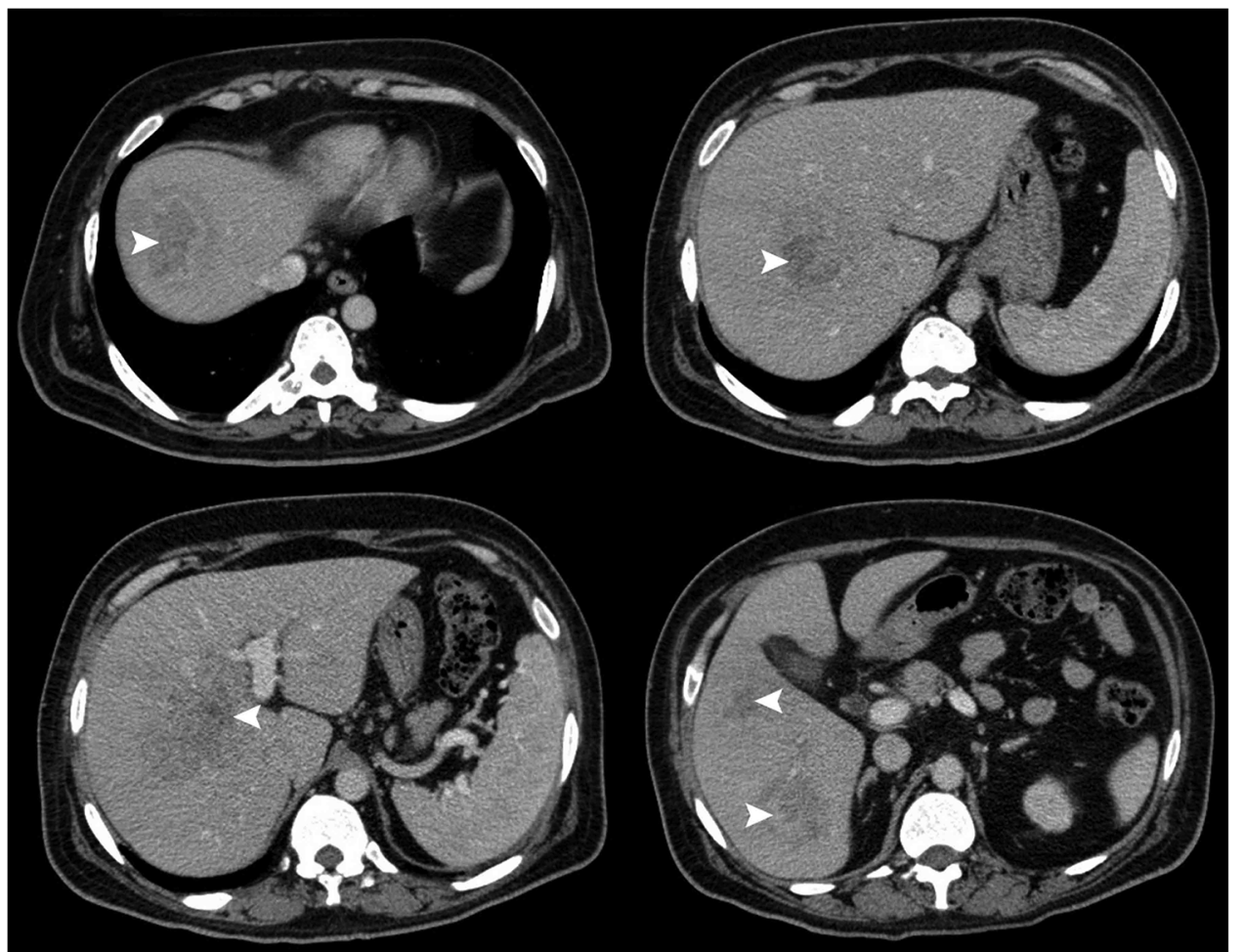

Figure 1 Axial CT of the abdomen with contrast demonstrating multiple ill-defined, hypodense lesions scattered throughout the liver, showing peripheral wall enhancement and central necrotic areas suggestive of abscesses (white arrowheads). 


\section{Learning points}

- Tuberculosis infection of the liver is generally described in immunocompromised patients with widespread miliary disease. Isolated affliction of the liver in the form of a tubercular abscess, especially in an immunocompetent patient, is extremely rare.

- Owing to the rarity of the disease and masquerading imaging findings, primary hepatic tubercular abscess poses a diagnostic dilemma, commonly confused with amoebic or pyogenic abscesses. Nonetheless, tuberculosis should be included as a possible aetiological factor while reviewing a case of liver abscess; especially in an endemic area.

- Tuberculosis is a treatable condition and thus increased awareness about diverse and unusual presentations of extrapulmonary tuberculosis is of paramount importance aiding in early management. primary hepatic tuberculosis, tuberculous cholangitis and tubercular abscess. ${ }^{1}$ Of these, tubercular abscess is rarest. ${ }^{2}$ It is even rarer in immunocompetent individuals. ${ }^{2}$ Clinical and radiological findings are non-specific and differentials include pyogenic or amoebic abscess. ${ }^{1}$ It may even mimic a hepatoma. ${ }^{1}$ The diagnosis relies on demonstration of AFB in the aspirate or a response to antitubercular treatment. ${ }^{2}$ Prognosis is favourable if diagnosed and treated in time.

Competing interests None.

Patient consent Obtained.

Provenance and peer review Not commissioned; externally peer reviewed.

\section{REFERENCES}

1 Baveja C, Gumma V, Chaudhary M, et al. Primary tubercular liver abscess in an immunocompetent adult: a case report. J Med Case Rep 2009;3:78.

2 Hassani $\mathrm{KI}$, Ousadden A, Ankouz A, et al. Isolated liver tuberculosis abscess in a patient without immunodeficiency: a case report. World J Hepatol 2010;2:354-7

Copyright 2014 BMJ Publishing Group. All rights reserved. For permission to reuse any of this content visit http://group.bmj.com/group/rights-licensing/permissions.

BMJ Case Report Fellows may re-use this article for personal use and teaching without any further permission.

Become a Fellow of BMJ Case Reports today and you can:

- Submit as many cases as you like

- Enjoy fast sympathetic peer review and rapid publication of accepted articles

- Access all the published articles

- Re-use any of the published material for personal use and teaching without further permission

For information on Institutional Fellowships contact consortiasales@bmjgroup.com

Visit casereports.bmj.com for more articles like this and to become a Fellow 